\title{
PRODUCTION AND EVALUATION OF POLYCLONAL ANTIBODIES AGAINST HOMOLOGOUS CITRUS TRISTEZA VIRUS (CTV) ISOLATES FROM PAKISTAN
}

\author{
Z. Abbas ${ }^{1,5}$, S. Hameed ${ }^{2}$, B. Lockhart ${ }^{3}$, S. Bratsch ${ }^{3}$, N. Olszewski ${ }^{4}$, Dur-e-shahwar ${ }^{1,5}$, M. A. Rehman ${ }^{6}$ and \\ S. M. Saqlan Naqvi ${ }^{1}$ \\ ${ }^{1}$ Department of Biochemistry, Pir Mehr Ali Shah Arid Agriculture University Rawalpindi, 46300, Pakistan \\ ${ }^{2}$ Pakistan Agriculture Research Council (PARC), G-5 Islamabad, Pakistan \\ ${ }^{3}$ Department of Plant Pathology, University of Minnesota, Saint Paul MN, 55113, USA \\ ${ }^{4}$ Department of Plant and Microbial Biology, University of Minnesota, Saint Paul MN, 55113, USA \\ ${ }^{5}$ DNA to Protein Technologies, Rawalpindi, Pakistan \\ ${ }^{6}$ Citrus Research Institute, Sargodha, Pakistan \\ Corresponding author's E-mail: zshah354@gmail.com
}

\begin{abstract}
Citrus tristeza virus (CTV) is a plant pathogenic virus first reported infecting citrus plants in the 1930's in Brazil and Argentina and is now widely spread through all citrus growing areas. A CTV isolate from an infected Pakistani sweet orange tree was selected for sequencing to subsequently produce recombinant CTV coat protein. The purified recombinant CTV coat protein was used as an antigen for the production of polyclonal antisera in rabbits. The antisera were tested in direct antigen coating enzyme linked immunosorbent assay (DAC-ELISA) against various CTV isolates from Pakistan and T-30 from the USA. The antisera reacted strongly in DAC-ELISA with both homologous and heterologous isolates of CTV from infected citrus leaf tissue. These antisera were compared with a commercially available ELISA kit and were more sensitive to Pakistani isolates of CTV than the commercial ELISA kit. An inexpensive virus-free testing and certification program using the antisera produced here would provide farmers with the knowledge to eliminate CTV infected and unproductive trees, which could then be replaced with healthy young trees. The implementation of such a scheme would reduce the incidence of CTV in citrus orchards, reduce yield losses caused by CTV, and could lead to the elimination of CTV from Pakistan
\end{abstract}

Keywords: CTV, DAC-ELISA, Antibodies, Polyclonal antisera, Coat protein

https://doi.org/10.36899/JAPS.2021.4.0302

Published online December 15, 2020

\section{INTRODUCTION}

In agricultural countries, plant viral diseases are a serious problem which can lead to reduced crop yields. Sometimes, the viral infections are symptomless as in the case of some strains of CTV (Bar Joseph et al., 1989) and sometimes the symptoms mimic abiotic diseases. Viral infections cannot be cured in the field unlike other plant pathogens including fungi, bacteria, oomycetes, and nematodes. To prevent losses due to viral infections there must be a disease management plan that relies upon testing and indexing of plants so that virus free certified plant buds can be generated and provided to farmers. For that purpose, ELISA can be an efficient tool because it is easily scalable, cost-effective and is a quantitative method for the detection of viruses (Clark and Adams, 1977).

ELISA has been used since 1978 to detect CTV for virus surveys, virus control, and academic purposes (Gonsalves et al., 1978; Mathew et al., 1997; Cambra et al., 2000). Initial antisera used in CTV detection ELISAs was prepared against whole virions (Gonsalves et al., 1978).). Antisera produced from whole virus particles may react with healthy plant extracts due to the presence of plant proteins in inoculated material (Marco and Gumpf, 1991). The development of CTV monoclonal antibodies was a major breakthrough because it primarily reacts with most severe strains of the virus (Vela et al., 1986; Permar et al., 1990). The development of antibody MCA-13 enabled differentiation of severe and mild strains from Florida using ELISA (Niblett et al., 2000). Polyclonal antibodies have been successfully produced against recombinant CP of CTV isolates MX08 and MX14 from Mexico and isolate B227 from India which were used as trapping and intermediated antibodies. (Cardenas et al., 2008). Polyclonal antibodies were also produced and analyzed against CTV isolate from Thailand (Shibru et al., 2014).

Citrus tristeza virus belongs to the genus Closterovirus and family Closteroviridae. It is a phloem limited virus that causes symptoms of stem pitting, quick decline, yellowing of seedlings and yield losses in mature citrus trees. CTV is spread by grafting of infected plants (most commonly from rootstock to scion) and by aphids including Toxoptera citricida, Aphis gossypii and Aphis spiraecola in a semi-persistent manner (Albiach-Marti et al., 2000). CTV is widely distributed in all citrus growing 
areas of the world due to the distribution of infected sour orange (Citrus aurantium) commonly used as a root stock. In the past CTV has caused the death of millions of citrus trees worldwide with more than 30 million trees reported in Brazil and Argentina during the 1930's, 10 million trees in Spain during the 1960's and 6.6 million trees in Venezuela during the 1980's (Rocha-Pena et al., 1995).

CTV has been detected in Pakistan since 1988 and has been identified via transmission electron microscopy (Catara et al., 1988; Grimaldi and Catara, 1989), serological methods like ELISA (Arif et al., 2005; Iftikhar et al., 2009; Arif et al., 2015) or direct tissue blot immunoassay (Atta et al., 2011), and molecular methods like PCR (Ammar et al., 2013; Atta et al., 2017; Abbas et $a l ., 2019)$. The CTV population in Pakistan consists of four different genotypic groups including $\mathrm{T}_{3}, \mathrm{VT}, \mathrm{RB}$ and VT India among which $T_{3}$ is the major group likely dispersed due to the exchange of uncertified buds among farmers (Abbas et al., 2019). As CTV is widespread in Pakistan it requires the introduction of a large-scale indexing and citrus protection programs to eliminate the spread of infected plants and reduce yield losses from CTV. An effective indexing program requires a cost-effective diagnostic tool to identify Pakistani CTV isolates in infected plant material. The currently available ELISA kits are heterologous and are imported from other countries which greatly increases the cost of CTV diagnosis. The objectives of this study were to produce polyclonal antibodies against recombinant coat protein $(\mathrm{rCP})$ of homologous CTV isolate from Pakistan and to evaluate the antibodies for use in diagnostic assays. To our knowledge this is the first study to produce polyclonal antibodies against a CTV isolate from Pakistan.

\section{MATERIALS AND METHODS}

Virus isolate and gene synthesis: The virus isolate Islamabad 91 (Accession \# MF 461395 on NCBI Genbank) was selected from the major CTV group in Pakistan $\left(\mathrm{T}_{3}\right.$ like) identified in our previous study (Abbas et al., 2019). The gene sequence (672 bp) $100 \%$ identical to Islamabad 91 was synthesized (University of Minnesota, USA) containing Gateway ${ }^{\circledR}$ cloning technology specific ATTB1

(GGGGACAA GTTTGTACAAAAAAGCAGGCTGG) and ATTB2 (GGGGACCACTTTGTACAAGAAA GCTGGGTG) sites at 5' and 3 ' ends.

Gene cloning: The synthesized fragment was recombined in to a Pi-DONR vector (Olszewski unpublished) by Gateway $^{\circledR}$ BP recombination reaction following manufacturer's protocol. Plasmid was purified from transformed clones (Plasmid isolation kit, Zymo research) and analyzed using AatII restriction enzyme. The recombinant Pi-DONR CTV CP clone was sub cloned by Gateway ${ }^{\circledR}$ LR recombination reaction in to the expression vector p-COLA2-DEST ${ }^{\mathrm{TM}}$ (Novagen plasmids) following manufacturers protocol. Plasmid was purified (Plasmid isolation kit, Zymo research) and analyzed by AatII restriction enzyme. The positive clones were also confirmed by sequencing using $\mathrm{T} 7$ promoter primers.

Protein expression: Escherichia coli Rosetta ${ }^{\mathrm{TM}} 2$ (DE3) and BL21 (DE3) were transformed with p-COLA2 recombinant plasmid and colonies were isolated on $\mathrm{LB}$ agar plates containing $25 \mu \mathrm{g} / \mathrm{mL}$ kanamycin and Rosetta cells media also contained $20 \mu \mathrm{g} / \mathrm{mL}$ chloramphenicol at $37^{\circ} \mathrm{C}$ overnight. A single colony was used to inoculate a 5 $\mathrm{mL}$ of LB medium supplemented with kanamycin and chloramphenicol as above and was grown overnight at $37^{\circ} \mathrm{C}$ with rotation at $200 \mathrm{RPM}$. The overnight culture was used to inoculate $500 \mathrm{~mL}$ of LB medium with same antibiotic concentrations as mentioned above. Cells were grown at $37^{\circ} \mathrm{C}$ with a rotation of $200 \mathrm{RPM}$ until an optical density of $\mathrm{OD}_{600}=0.5$ was obtained. Protein expression was induced in the cells by a final concentration of $0.5 \mathrm{mM}$ IPTG and allowed to grow for 4 hours at $37^{\circ} \mathrm{C}$ with a rotation of 200 RPM. The induced and uninduced fractions were analyzed by $15 \%$ SDS-PAGE. The induced culture was pelleted down at $7500 \mathrm{RPM}$ at $4^{\circ} \mathrm{C}$ for 25 minutes.

Cell Lysis (French press): For $500 \mathrm{~mL}$ induced cells, cell pellets were resuspended in $10 \mathrm{~mL}$ of sodium phosphate buffer $\left(50 \mathrm{mM} \mathrm{NaPO}_{4}, 300 \mathrm{mM} \mathrm{NaCl}, \mathrm{pH} 7.0\right)$. Cells were lysed by using pressure of 1100 Pascal $(\mathrm{Pa})$ in a standard French press protocol. The whole protocol was repeated twice. Lysed cells were clarified by centrifugation at $7000 \mathrm{~g}$ for 25 minutes at $4^{\circ} \mathrm{C} .10 \mu \mathrm{L}$ aliquots were analyzed by $15 \%$ SDS-PAGE to check the solubility of the expressed protein.

Protein solubilization and purification: After cell lysis the protein was purified by two different methods. In the first method the protein was concentrated by centrifugation of the inclusion bodies at $7000 \mathrm{xg}$ for 25 minutes at $4{ }^{\circ} \mathrm{C}$. The resultant pellet was clarified by resuspension in sodium phosphate buffer containing $0.5 \%$ triton X-100 followed by centrifugation at $7000 \mathrm{xg}$ for 25 minutes. The pellet was solubilized by resuspension in $10 \mathrm{~mL}$ of sodium phosphate buffer containing 6 molar guanidinium hydrochloride and incubated at room temperature for 1 hour. The solubilized protein was clarified by centrifugation at $7000 \mathrm{xg}$ for 25 minutes at $4^{\circ} \mathrm{C}$. Both supernatant and pellet were allowed to run on $15 \%$ SDS-PAGE. The solubilized protein was purified by TALON $^{\circledR}$ METAL Affinity Resin using Batch/GravityFlow Column purification protocol (TaKaRa Bio, USA). The concentration of the purified protein was analyzed by Bradford assay.

The second method concentrated the inclusion bodies by centrifugation at 14000 RPM for 20 minutes. The pellet was suspended in $10 \mathrm{~mL}$ of sodium phosphate buffer and centrifuged again. The pellet was completely 
resuspended in $10 \mathrm{~mL}$ of buffer $(50 \mathrm{mM}$ Tris $\mathrm{HCl} \mathrm{pH} \mathrm{7.4,}$ $1 \mathrm{mM}$ EDTA) and centrifuged at 14000RPM for 20 minutes. The resultant pellet was completely resuspended in $5 \mathrm{~mL}$ of SDS-loading buffer $(250 \mathrm{mM}$ Tris $\mathrm{HCl} \mathrm{pH} \mathrm{6.8,}$ $8 \% \mathrm{w} / \mathrm{v}$ SDS, $0.2 \% \mathrm{w} / \mathrm{v}$ Bromophenol blue, $40 \% \mathrm{v} / \mathrm{v}$ glycerol, $20 \% \mathrm{v} / \mathrm{v} \beta$-mercaptoethanol) and heated at $95^{\circ} \mathrm{C}$ for 5 minutes. Solution was cleared by centrifugation at 14000RPM for 20 minutes. Supernatant was run on the $15 \%$ SDS-PAGE as $0.1 \mu \mathrm{L}, 1 \mu \mathrm{L}$ and $5 \mu \mathrm{L}$ volume.

Two SDS-PAGE (15\%) containing eight wells of $3 \mathrm{~cm}$ were prepared and each well was loaded with $40 \mu \mathrm{L}$ of the supernatant obtained in the second method described above. Gels were stained with coomassie brilliant blue stain and the bands for the protein of interest were cut out.

Production of antisera: The excised protein bands were sent to the company (Pacific Immunology Corp Ramona, CA, USA) for raising polyclonal antibodies in two rabbits of New Zealand breed. 100-day plan for raising antibodies was given by the company (Table 1). Antigen was injected subcutaneously around the shoulders of the rabbits with Freud's complete adjuvant (First immunization) and Freud's incomplete adjuvant (second, third and fourth immunization).

Table 1. Hundred days plan provided by company (Pacific immunology corp) for producing antisera in rabbits.

\begin{tabular}{|c|c|}
\hline Day & Process \\
\hline Day 1 & Immunize with Complete Freund's adjuvant \\
\hline Day 20 & $\begin{array}{c}\text { Immunize with Incomplete Freund's } \\
\text { adjuvant }\end{array}$ \\
\hline Day 42 & $\begin{array}{c}\text { Immunize with Incomplete Freund's } \\
\text { adjuvant }\end{array}$ \\
\hline Day 50 & Production bleed \\
\hline Day62 & Production bleed \\
\hline Day 69 & $\begin{array}{l}\text { Immunize with Incomplete Freund's } \\
\text { adjuvant }\end{array}$ \\
\hline Day 77 & Production bleed \\
\hline Day 87 & Production Bleed \\
\hline Day 97 & Final Bleed part 1 \\
\hline Day & Final Bleed part 2 \\
\hline 100 & \\
\hline
\end{tabular}

Western Blot: The protein purified by the method mentioned above was run on $15 \%$ SDS-PAGE and western blotting was performed according to protocol (Mahmood and Yang, 2012) using 1:10,000 (v/v) dilution of antiserum.

DAC ELISA: The Last four Bleeds of antisera were tested by DAC-ELISA. Nunc Maxisorp 96 well plates were coated with $100 \mu \mathrm{L}$ of either a healthy control of sweet orange leaf tissue or sweet orange leaf tissue infected with CTV T-30 (Dr. Bill Dawson, University of Florida, USA). The leaf tissues were extracted 1:20 (w/v) in ELISA carbonate coating buffer, $\mathrm{pH}$ 9.6. Samples were incubated at $37^{\circ} \mathrm{C}$ for 1 hour. Antigen coated plates were rinsed two times with $\mathrm{NaKPO}_{4}(\mathrm{pH}$ 8.6) for 30 minutes and blocked with $5 \%(\mathrm{w} / \mathrm{v})$ nonfat dry milk (NDM) in $20 \mathrm{mM} \mathrm{NaKPO}_{4}$ ( $\mathrm{pH}$ 8.6) for 30 minutes at room temperature. Whole serum diluted 1:10,000-1:80,000 in 5\% NDM in phosphate buffer saline $\quad$ tween ${ }^{\circledR} 20($ PBST $) \quad$ containing $2 \% \quad(\mathrm{w} / \mathrm{v})$ polyvinylpyrrolidone (PVP) $(40,000 \mathrm{MW})$ and $0.2 \%(\mathrm{w} / \mathrm{v})$ bovine serum albumin (BSA) were added to each well and incubated at $37^{\circ} \mathrm{C}$ for 1 hour. Five rinses with PBST were followed by the application of monoclonal anti-rabbit IgGAP conjugate (Sigma Cat No A25556) diluted 1:10,000 $(\mathrm{v} / \mathrm{v})$ in PBST-PVP-BSA containing 5\% NDM and incubation at $37^{\circ} \mathrm{C}$ for 1 hour. After rinsing five times with PBST $0.5 \mathrm{mg} / \mathrm{mL}$-Nitrophenyl phosphate (pNPP) in diethanolamine substrate buffer ( $\mathrm{pH}$ 9.8) was added and incubated at room temperature for 2 hours. Absorbance was measured at $405 \mathrm{~nm}$. Samples were repeated four times.

The sensitivity of the antiserum was tested using dilutions of infected plant extract from 1:10-1:100 (w/v) in ELISA carbonate coating buffer. The protocol described above was followed except only a 1:10,000 (v/v) dilution of antisera was used. The samples were repeated three times.

Twelve symptomatic samples were tested by RTPCR as described in Abbas et al., (2019), for CTV and then used to check the sensitivity and specificity of antisera by DAC ELISA as described above using a 1:10,000 (v/v) dilution of CTV antisera from rabbit 1. Samples were tested in triplicate. The same twelve samples were also tested with a commercially available double antibody sandwich enzyme linked immunosorbent assay (DASELISA) kit from AGDIA ${ }^{\circledR}$ following the manufacturer's protocol (AGDIA, Inc. IN, USA).

\section{RESULTS}

Protein expression: Sequencing of the p-COLA2DEST $^{\mathrm{TM}}$ expression clones confirmed the presence of the gene of interest in the vector. Protein expression was carried out in E. coli Rosetta (DE3) and BL21 cells. The expected protein band of $27 \mathrm{kDa}$ was expressed more strongly in BL21 than in Rosetta (Fig. 1a and 1b).

Protein Purification: The expressed rCP of CTV is not soluble (Fig. 2). The protein was solubilized and purified. SDS-PAGE of the purified fractions revealed that $\mathrm{rCP}$ was not contaminant free (Fig. 3a). Bradford assay determined a maximum total protein quantity of approximately 100 $\mu \mathrm{g} / \mathrm{mL}$ which was not enough for antibody production. To increase the purity and amount of protein the inclusion bodies were further processed as explained above. Results of SDS-PAGE of the second round of purified CTV rCP revealed that band intensity of even $0.1 \mu \mathrm{L}$ loaded volume 
was greater than the band intensity of $20 \mu \mathrm{L}$ of the TALON $^{\circledR}$ METAL Affinity Resin purified fractions. The majority of protein was $27 \mathrm{kDa}$ which is the expected size of the CTV rCP (Fig. 3b). There were also minor bands of other contaminating proteins which had to be eliminated. For this purpose, $40 \mu \mathrm{L}$ fractions of the solubilized protein was run on SDS- PAGE and rCP was cut out of the gel. The final yield of rCP was estimated to be $16 \mathrm{mg}$.

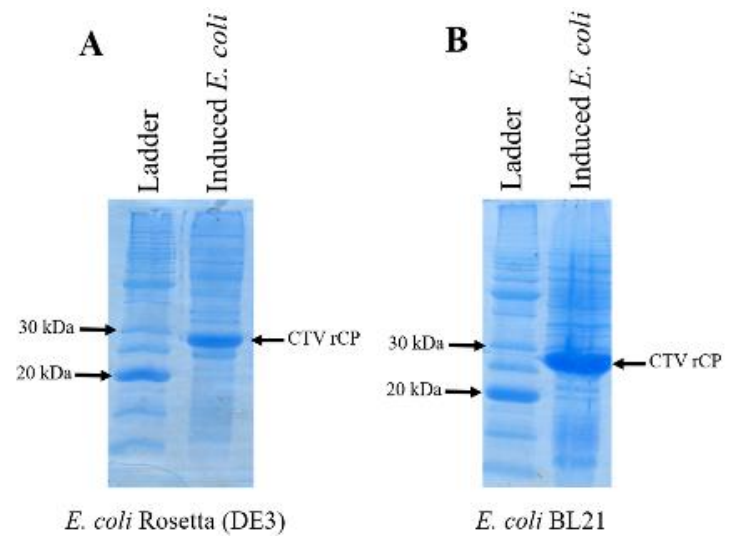

Fig. 1. 15\% SDS-PAGE to detect the amount of protein expressed by the pCOLA-2-DEST TM CTVCP vector in $E$. coli Rosetta ${ }^{\text {TM }}$ (DE3) (A) and BL21 (B). A $20 \mu \mathrm{L}$ fraction of induced whole cells was analyzed for both $E$. coli strains and a band of $27 \mathrm{kDa}$ corresponding to the predicted size of CTV rCP was observed for both strains. A larger amount was produced by the BL21 strain.

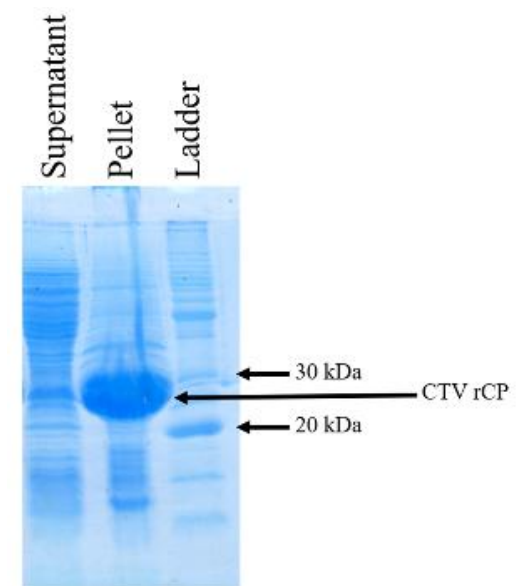

Fig. 2. 15\% SDS-PAGE analyzing the proteins in the supernatant and pellet after cell lysis. CTV rCP at $27 \mathrm{kDa}$ was observed in the insoluble pellet fraction only.
A

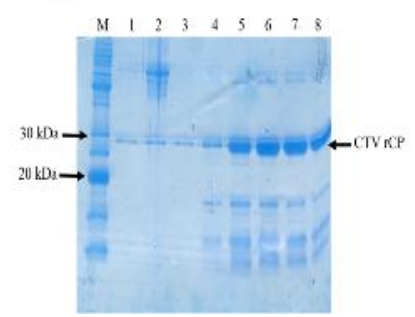

B

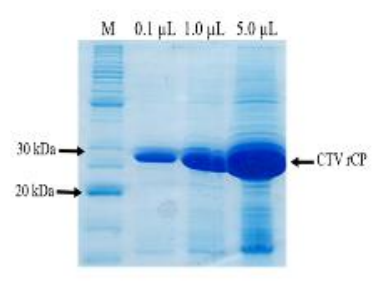

Fig. 3. (A) 15\% SDS PAGE for the purified fractions of recombinant CTV CP after purification by Talon $^{\circledR}$ Metal Affinity Resin. $20 \mu \mathrm{L}$ of the eluted fractions 1-8 were loaded in each well. Fractions 5 - 8 contain the highest protein. (B) $15 \%$ SDS PAGE for protein solubilized in SDS-Loading buffer. Gel was loaded with $M$ (protein ladder), $0.1,1$ and $5 \mu \mathrm{L}$ of solubilized CTV rCP.

Antisera production and evaluation: The antisera were produced in two rabbits and were obtained in the form of six different bleeds. These bleeds were evaluated by western blotting and DAC ELISA against homologous and heterologous CTV isolates. Results from the western blot showed the binding of purified CTV rCP confirming the specificity of antisera (Fig. 4).

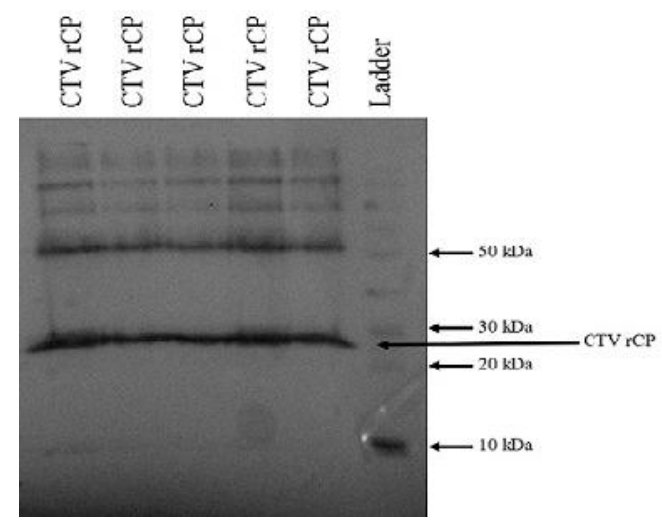

Fig 4. Image of the polyvinedyl diflouride (PVDF) membrane showing results of the western blot. Black color showing the binding of antibodies to the recombinant CTV CP in monomeric (27 $\mathrm{kDa})$, dimeric (54 kDa), trimeric $(81 \mathrm{kDa})$ and more.

Initially the final five bleeds of antisera were tested against healthy lyophilized sweet orange leaf tissue and lyophilized sweet orange leaf tissues infected with CTV isolate T30. For all bleeds the absorbance values decreased as the antiserum dilution increased. The fifth and sixth bleeds had the highest absorbance for both rabbits however there was only a minor change between the two bleeds ( 0.965 to 0.924 for rabbit 1 and 0.185 to 0.211 for rabbit 2) (Table $2 a$ and $2 b$ ). 
Table 2a: ELISA readings of the antiserum from rabbit 1. Readings for the four dilutions of last five bleeds for healthy $(\mathrm{H})$ and virus possessing $(\mathrm{V})$ tissues are mentioned. Readings are mean of triplicates.

\begin{tabular}{|c|c|c|c|c|c|c|c|c|c|c|}
\hline \multirow{2}{*}{$\begin{array}{l}\text { Antiserum } \\
\text { dilutions }\end{array}$} & \multicolumn{2}{|c|}{ Second bleed } & \multicolumn{2}{|c|}{ Third bleed } & \multicolumn{2}{|c|}{ Fourth bleed } & \multicolumn{2}{|c|}{ Fifth bleed } & \multicolumn{2}{|c|}{ Last bleed } \\
\hline & $\mathbf{H}$ & $\mathbf{V}$ & $\mathbf{H}$ & V & $\mathbf{H}$ & $\mathbf{V}$ & $\mathbf{H}$ & $\mathbf{V}$ & $\mathbf{H}$ & $\mathbf{V}$ \\
\hline $1 / 10000$ & 0.023 & 0.751 & 0.024 & 0.880 & 0.012 & 0.790 & 0.014 & 0.965 & 0.020 & 0.924 \\
\hline $1 / 20000$ & 0.010 & 0.475 & 0.013 & 0.580 & 0.002 & 0.514 & 0.004 & 0.650 & 0.004 & 0.618 \\
\hline $1 / 40000$ & 0.004 & 0.292 & 0.001 & 0.350 & 0.00 & 0.315 & 0.00 & 0.410 & 0.00 & 0.398 \\
\hline $1 / 80000$ & 0.003 & 0.166 & 0.001 & 0.220 & 0.00 & 0.182 & 0.00 & 0.258 & 0.00 & 0.258 \\
\hline
\end{tabular}

Table 2b: ELISA readings of the antiserum from rabbit 2. Readings for the four dilutions of last five bleeds for healthy $(\mathrm{H})$ and virus possessing $(\mathrm{V})$ tissues are mentioned. Readings are mean of triplicates.

\begin{tabular}{|c|c|c|c|c|c|c|c|c|c|c|}
\hline \multirow{2}{*}{$\begin{array}{l}\text { Antiserum } \\
\text { dilutions }\end{array}$} & \multicolumn{2}{|c|}{ Second bleed } & \multicolumn{2}{|c|}{ Third bleed } & \multicolumn{2}{|c|}{ Fourth bleed } & \multicolumn{2}{|c|}{ Fifth bleed } & \multicolumn{2}{|c|}{ Last bleed } \\
\hline & $\mathbf{H}$ & $\mathbf{V}$ & $\mathbf{H}$ & $\mathbf{V}$ & $\mathbf{H}$ & $\mathbf{V}$ & $\mathbf{H}$ & $\mathbf{V}$ & $\mathbf{H}$ & $\mathbf{V}$ \\
\hline $1 / 10000$ & 0.005 & 0.120 & 0.006 & 0.236 & 0.00 & 0.229 & 0.00 & 0.185 & 0.00 & 0.211 \\
\hline $1 / 20000$ & 0.007 & 0.070 & 0.006 & 0.132 & 0.006 & 0.138 & 0.00 & 0.108 & 0.00 & 0.129 \\
\hline $1 / 40000$ & 0.002 & 0.035 & 0.00 & 0.073 & 0.00 & 0.072 & 0.00 & 0.055 & 0.00 & 0.068 \\
\hline $1 / 80000$ & 0.00 & 0.020 & 0.00 & 0.031 & 0.00 & 0.043 & 0.00 & 0.022 & 0.00 & 0.038 \\
\hline
\end{tabular}

ELISA readings of the antisera from rabbit 1 were consistently higher than the rabbit 2 . Antisera from rabbit 1 could detect virus in plant tissue diluted up to 1: 100 while rabbit 2 antisera could only detect up to 1:50 dilution (Table 3 ).

Table 3: Comparison of the reactivity of final bleed of antiserum from both rabbits with five different dilutions of diseased plant extract. Column 1 and 2 are the readings of reactivity of antisera from rabbit 1 and 2 with different dilutions of the diseased plant extract i.e. 1/10, 1/25, 1/50, 1/75 and 1/100. Healthy Plant extract was diluted in minimum volume (1:10) of the buffer. Readings are the mean of four treatments per sample. Positive value is 2.5 times the value of healthy.

\begin{tabular}{ccc}
\hline & 1 & 2 \\
\hline$(1 / 10)$ & 1.901 & 0.511 \\
$(1 / 25)$ & 1.576 & 0.351 \\
$(1 / 50)$ & 1.143 & 0.218 \\
$(1 / 75)$ & 0.834 & 0.141 \\
$(1 / 100)$ & 0.538 & 0.100 \\
Healthy & 0.175 & 0.086 \\
\hline
\end{tabular}

Twelve symptomatic plant samples were tested by RT-PCR which gave positive results for all the samples. Eleven out of twelve of the samples showed low band intensities on agarose gel (Fig. 5).

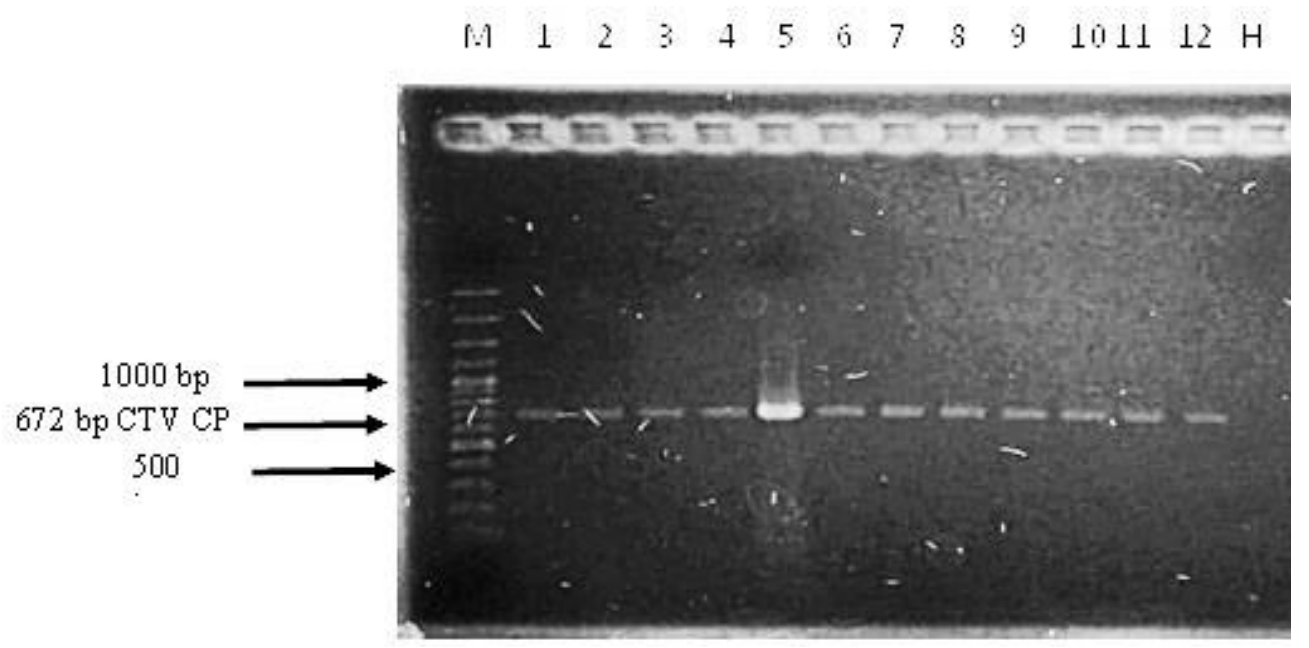

Fig 5: Gel electrophoresis of the PCR product of twelve CTV positive samples 1-12 from Pakistan used as homologous isolates in this study. $10 \mu \mathrm{L}$ volume of PCR product of each sample was loaded. 
These RT-PCR positive plants were tested by ELISA and used to compare with the commercially available DAS ELISA kit. The results showed significant difference between the results from our prepared antisera used in DAC ELISA and the commercially available DAS ELISA kit. Our antisera gave positive results with all twelve Pakistani CTV samples whereas only two samples tested positive with the commercially available DASELISA kit. In DAC ELISA no significant increase in the reading of negative control was observed after different intervals of substrate incubation i.e. after $2 \mathrm{~h}, 3 \mathrm{~h}$ and overnight but readings of the positive samples increased significantly after overnight substrate incubation. (Table $4)$.

Table 4. Comparison of antiserum produced in the current study and the commercially available Kit from Agdia ${ }^{\circledR}$ with Pakistani isolates. Samples under observation are from serial number 1 to 12 . Serial number 13 showed the value of negative control. For Agdia $^{\circledR}$ DAS ELISA absorbance after 1 hour after substrate incubation was considered conclusive as recommended in the kit whereas for DAC ELISA absorbance readings after different intervals of substrate incubation were measured. Any value 2.5 times the value of healthy was considered positive.

\begin{tabular}{llllcccc}
\hline & \multicolumn{3}{l}{ DAC 1:10,000 } & \multicolumn{3}{c}{ DAS Agdia $^{\circledR} \mathbf{1 : 2 0 0}$} & RT PCR \\
\hline Sr\# & $\mathbf{2}$ hours & $\mathbf{3}$ hours & overnight & I/H & $\mathbf{1 ~ h o u r}$ & $\mathbf{I} / \mathbf{H}$ & \\
1 & 0.268 & 0.353 & 0.770 & $\mathbf{I}$ & 0.252 & $\mathbf{H}$ & + \\
2 & 0.282 & 0.371 & 0.826 & $\mathbf{I}$ & 0.178 & $\mathbf{H}$ & + \\
3 & 0.284 & 0.360 & 0.783 & $\mathbf{I}$ & 0.608 & $\mathbf{I}$ & + \\
4 & 0.297 & 0.387 & 0.850 & $\mathbf{I}$ & 0.172 & $\mathbf{H}$ & + \\
5 & 0.300 & 0.387 & 0.872 & $\mathbf{I}$ & 3.158 & $\mathbf{I}$ & + \\
6 & 0.301 & 0.388 & 0.853 & $\mathbf{I}$ & 0.260 & $\mathbf{H}$ & + \\
7 & 0.309 & 0.407 & 0.889 & $\mathbf{I}$ & 0.401 & $\mathbf{H}$ & + \\
8 & 0.294 & 0.383 & 0.845 & $\mathbf{I}$ & 0.213 & $\mathbf{H}$ & + \\
9 & 0.272 & 0.349 & 0.741 & $\mathbf{I}$ & 0.275 & $\mathbf{H}$ & + \\
10 & 0.266 & 0.344 & 0.756 & $\mathbf{I}$ & 0.335 & $\mathbf{H}$ & + \\
11 & 0.305 & 0.400 & 0.901 & $\mathbf{I}$ & 0.379 & $\mathbf{H}$ & + \\
12 & 0.334 & 0.438 & 0.982 & $\mathbf{I}$ & 0.349 & $\mathbf{H}$ & + \\
$\mathbf{1 3}$ & $\mathbf{0 . 0 6 5}$ & $\mathbf{0 . 0 6 7}$ & $\mathbf{0 . 0 7 1}$ & & $\mathbf{0 . 1 8 3}$ & & - \\
\hline
\end{tabular}

\section{DISCUSSION}

In the current study the rCP of CTV was expressed in two different strains of E. coli Rosetta $^{\circledR}$ and BL21) and a higher level of expression was observed in BL21. The expected size of $27 \mathrm{kDa}$ of $\mathrm{rCP}$ was observed in contrast with the study of Sadeghan et al. (2013) in which they reported the appearance of truncated protein of size $14 \mathrm{kDa}$ when expressed in BL21. They concluded that the presence of two consecutive low usage codons CUU (for leucine) and CGA (for arginine) at position 136 and 137 prevents the expression of full protein. Our expressed sequence of coat protein from Islamabad91 also contained these two consecutive low usage codons at the same positions but we have not found any truncated protein. This indicates that the expression of truncated protein in the study of Sadeghan et al. (2013) is not due to the presence of above mentioned codons, but instead is caused by some other factor which may be the usage of different plasmid backbone, over expression due to a higher IPTG concentration (our $0.5 \mathrm{mM}$ vs their $1.0 \mathrm{mM}$ induction concentration), or some other differences in the two sequences. We confirmed a lower expression of CTV rCP in Rosetta ${ }^{\circledR}$ in comparison to BL21.
The final antiserum bleed from rabbit 1 was used at a dilution of $1: 10,000$ to detect CTV rCP in a western blot. The antibody readily detected $\mathrm{rCP}$ in both monomeric and multimeric forms. In addition to confirmation, this antiserum is able to detect CTV CP in denatured conditions (which it was raised against), this also indicated the antiserum would effectively identify whole CTV virions

Six total antiserum samples were obtained for both rabbits during the 100-day antiserum production. The final antiserum produced under the same conditions showed rabbit 1 had a 4.5 times stronger reaction to infected tissue at a 1:10,000 (v/v) dilution in comparison with rabbit 2 . Rabbit 2 consistently had a greatly reduced reaction in comparison with rabbit 1 . Rabbit 1's antiserum titer peaked at bleed 5 with the highest absorbance of 0.965 while the final bleed was 0.924 . The antisera obtained from rabbit 1 had minimal reactions to healthy tissue with absorbance of 0.014 (fifth bleed) and 0.02 (final bleed). This corresponds to an infected to healthy ratio of 69 and 46 , respectively, making both of the final two bleeds of antiserum excellent candidates for use in additional experiments.

One problem with CTV detection is the low virus titer in the plant at different time periods during the year 
(Mathew et al., 1997; Dodds et al., 1987). To determine the lowest plant dilution that our antiserum could detect CTV, we tested plant dilutions ranging from $1: 10(\mathrm{w} / \mathrm{v})$ to 1:100 (w/v). This test was done using fresh leaf tissue. When fresh tissue was used rabbit 2's antiserum had a higher reactivity than in comparison with the previously tested dried tissue ( 0.5 vs 0.2 , a $140 \%$ increase). Similarly, rabbit 1 had a higher reactivity to fresh tissue than dried ( 1.901 vs 0.924 a $100 \%$ increase). Rabbit 1 's antiserum could detect a CTV positive sample up to a 1:100 (w/v) dilution of plant tissue (the highest dilution tested), indicating it could be used to detect a low virus titer

Results of the DAC ELISA revealed that this antiserum can bind to both homologous and heterologous isolates. The present study showed that our antisera is more specific to Pakistani CTV isolates than commercial kit from $\operatorname{Agdia}^{\circledR}$. We have observed that all the samples which were negative with commercial kit but positive with our antisera were showing low band intensities with RTPCR which indicated that these plants had low virus titer. Sample \# 3 and sample \# 5 had value of 0.608 and 3.15 with Agdia $^{\circledR}$ but had value of 0.783 and 0.872 with our antisera (Table 4). These findings also indicated the epitopic diversity of CTV in our region. It is likely that sample \#5 is closely related to the isolates against which $\operatorname{Agdia}^{\circledR}$ antisera was raised. That is why, it has higher distinctive value with Agdia $^{\circledR}$. It is likely that sample \# 3 has some common set of epitopes to which Agdia ${ }^{\circledR}$ and our antisera both reacted equally. Sample\#3 also had low band intensity with RT-PCR but reacted well with Agdia $^{\circledR}$ which indicated that some differences in epitopes along with less virus titer lead to the low spectrophotometric readings of other ten samples with $\operatorname{Agdia}^{\circledR}$. $\operatorname{Agdia}^{\circledR}$ recommended 1:200 dilution of antibody whereas our antisera gave successful results even with 1:10,000 dilution which ultimately correlate to much less consumption of antisera and it is useful for economically testing large number of plants. DAC ELISA from our antisera revealed a very specific reaction to the presence of CTV against many different isolates but minimal reaction to healthy controls, even after an overnight incubation. These findings indicate our rCTV polyclonal antisera is very effective to detect numerous prevalent strains of CTV in Pakistan and that it does not give false positives.

Conclusion: As CTV is widely present in the citrus fields of Pakistan a management programe to eradicate this disease from the country is needed to reduce yield losses from CTV. The management requires the indexing of citrus trees and citrus buds for sale or trade. Antisera produced in this study will be helpful in developing a diagnostic tool for the indexing of citrus plants for CTV. Starting a certification programs by purchasing and importing ELISA kits for CTV from other countries cost prohibitive. Locally developed diagnostic tools can help to start producing virus free nurseries and certification schemes which would help in eliminating CTV from Pakistan.

\section{REFERENCES}

Abbas, Z., S. Hameed, S. Bratsch, B. Lockhart, Y. Zafar, and S.M.S. Naqvi (2019). Variation in the coat protein gene among citrus tristeza virus isolates from Khyber Pakhtunkhwa and Punjab provinces, and Islamabad capital territory of Pakistan. Intl. J. Agric. Biol. 21: 1221-1227.

Albiach-Marti, M.R., J. Guerri, A.H. de-Mendoza, F. Laigret, J.F. Ballester-Olmos, and P. Moreno (2000). Aphid transmission alters the genomic and defective RNA populations of Citrus tristeza virus isolates. Phytopathology 90: 134-138.

Ammar, M., S. Hameed, I. Haque, S.M. Mughal, H. Riaz, R. Parveen, and G. Yasmeen (2013). Serological Identification of Citrus Tristeza Closterovirus (CTV) and Molecular Characterization of its Coat Protein gene. Pakistan J. Phytopathol. 25:23-26.

Arif, M., A. Ahmad, M. Ibrahim, and S. Hassan (2005). Occurrence and distribution of virus and virus like diseases of citrus in north-west-frontier province of Pakistan. Pakistan J. Bot. 37(2): $407-$ 421

Arif, M., W. Khan, M. Ibrahim and M. Fahim (2015). Citrus tristeza virus: An increasing trend in the virus occurrence and distribution in citrus fruits of Northwest, Pakistan. Afric. J. Biotechnol. $14: 2352-2360$

Atta, S., Y. Zhou, X. Wang, and M. Cao (2011). Molecular characterization of citrus tristeza virus isolates from Pakistan based on CPG/ Hinf I RFLP groups analysis. Afric. J. Biotechnol. 10(44): 8689-8694

Atta, S., M. Cao, U. Umar, Y. Zhou, F. Yang, and C. Zhou (2017). Biological indexing and genetic analysis of citrus tristeza virus in Pakistan. J. Gen. Plant Pathol. 83: 382-389

Bar-Joseph, M., R. Marcus, and R.F. Lee (1989). The continuous challenge of Citrus tristeza virus control. Annu. Rev. Phytopathology 27: 291-361.

Catara, A., A. Azzaro, S.M. Mughal, and D. A. Khan (1988). Virus, Viroid and prokaryotic diseases of Citrus in Pakistan. Proc. Intl. Citrus Cong., 2: 957-962

Cambra, M., M.T. Gorris, C. Marroguin, M.P. Roman, A. Olmos, M.C. Martinez, A.H. de- Mendoza, A. Lopez, and L. Navarro (2000). Incidence and epidemiology of citrus tristeza virus in the Valencian community of Spain. Vir. Res. 71(12): 85-95.

Cardenas, M.I, B.D. Sandoval-Alejos, M.E. RomanCalderon, K.L. Manjunath, R.F. Lee, and M.A. Rocha-Pena (2008). Production of polyclonal 
antibodies to the recombinant coat protein of citrus tristeza virus and their effectiveness for virus detection. J. Phytopathol.. 156(4): 243-250.

Clark, M.F, and A.N. Adams (1977). Characteristics of the microplate method of enzyme-linked immunosorbent assay for the detection of plant viruses. J. Gen. Virol. 34: 475-483.

Dodds, J.A, T. Jarupat, J.G. Lee, and C.N. Roistacher (1987). Effect of strain, host, time of harvest, and virus concentration on double-stranded RNA analysis of citrus tristeza virus. Phytopathology 77 (3): 442-447.

Gonsalves, D., D.E. Purcifull, and S.M. Garnsey (1978). Purification and serology of citrus tristeza virus. Phytopathology 68: 553-559.

Grimaldi, V., and A. Catara (1989). Detection of Citrus tristeza and greening in Pakistan through electron microscopy. J. Phytopathol. 126:17-21.

Iftikhar, Y., M.A. Khan, A. Rashid, S.M. Mughal, Z. Iqbal, A. Batool, M. Abbas, M.M. Khan, S. Muhammad, and M.J. Jaskani (2009). Occurrence and distribution of citrus tristeza closterovirus in the Punjab and NWFP, Pakistan. Pak. J. Bot. 41(1): 373-380

Marco, G.M., and D.J. Gumpf (1991). A simple technique for the production of highly specific polyclonal antisera for citrus tristeza virus. Proc. Intl. Citr. Virol. Conf., (1957-2010). 11(11).

Mathews, D.M., K. Riley, and J.A. Dodds (1997). Comparison of detection methods of Citrus tristeza virus in field trees during months of nonoptimal titer. Plant. Dis.81: 525-529.

Mahmood, T., and P.C. Yang (2012). Western Blot:
Technique, theory, and trouble shooting. N. Am. J. Med. Sci. 4(9): 429-434.

Niblett, C.L., H. Genc, B. Cevik, S. Halbert, L. Brown, G. Nolasco, B. Bonacalza, K.L. Manjunath, V.J. Febres, H.R. Pappu, and R.F. Lee (2000). Progress on strain differentiation of Citrus tristeza virus and its application to the epidemiology of citrus tristeza disease. Vir. Res.71:97-106.

Permar, T., S.M. Garnsey, D.J. Gumpf, and R.F. Lee (1990). A monoclonal antibody that discriminates strains of citrus tristeza virus. Phytopathology.80: 224-228.

Rocha-Pena, M.A., R.F. Lee, R. Lastra, C.L. Niblett, F.M. Ochoa-Corona, S.M. Garnsey, and R.K. Yokomi (1995). Citrus tristeza virus and its aphid vector Toxoptera citricidathreats to citrus production in the Caribbean and central and North America. Plant Dis.79: 437-445

Sadeghan, A.A., M. Shams-Bakhsh, and B.Yakhchali (2013). Expression of citrus tristeza virus coat protein gene in Escherichia coli. J. Crop Protection 2(4); 387-393.

Shibru, S., A. Paradornuwat and S. Chowpongpang (2014). Expression of recombinant coat protein (CP) of citrus tristeza virus for polyclonal antibodies production. Asian J. Agric. Res. 8(2): 114-120.

Vela. C., M. Cambra, E. Cortes, P. Moreno, J.G.Miguet, C.P. de San Roman, and A.J. Sanz (1986). Production andcharacterization of monoclonal antibodies specific for citrus tristeza virus and their use of diagnosis. J. Gen.Virol.67: 91-9. 